\title{
REGULATION OF THE AMMONIA NITROGEN CONCENTRATION AT THE METHANE FERMENTATION OF CHICKEN MANURE UNDER CONDITIONS OF THE LIQUID PHASE RECIRCULATION
}

\author{
Ye. Shapovalov, S. Zhadan, A. Salyuk, A. Kotinskiy \\ National University of Food Technologies
}

\begin{tabular}{l}
$\quad$ Key words: \\
Methane fermentation \\
Chicken manure \\
Ammonia nitrogen \\
Modeling \\
Recirculation \\
Liquid phase \\
\hline
\end{tabular}

Article history:

Received 09.11.2018

Received in revised form

23.11.2018

Accepted 21.12.2018

Corresponding author:

Ye. Shapovalov

E-mail:

npnuht@ukr.net

\begin{abstract}
In the article an estimation of efficiency of a new method of regulation of ammonia nitrogen concentration during methane fermentation of chicken manure under conditions of liquid phase recirculation is presented. The essence of the method is the absorption of ammonia from the gas phase by non-volatile sorbent, which is located directly in the reactor, but not in contact with the substrate. The modeling of ammonium nitrogen concentration during the production of biogas from chicken manure in semi-continuous mode without ammonia removal and with ammonia removal was carried out. The results obtained in the research of removal of ammonium nitrogen from solutions of ammonium salt, which simulate a substrate with a high concentration of the inhibitor, in the periodic mode were used. Phosphoric acid was used as a sorbent, because it is able to react with ammonia, it is non-volatile, as a result of the reaction, a product that is useful for agriculture is formed. It is accepted that the process is carried out in the thermophilic mode at the temperature of $50^{\circ} \mathrm{C}$, the substrate moisture content of $90 \%$, and the hydraulic retention time of 5 and 10 days. The concentration of phosphoric acid was $4 \mathrm{~mol} / \mathrm{dm}^{3}$. The $\mathrm{pH}$ of the medium is assumed to be 7.5, 8.0 and 8.5. The ratio of the area of the sorbent and the substrate was 1:4.6, and the diameter of the apparatus and the depth of the substrate - 1:1.5. The maximum degree of the effluent recirculation of $60 \%$, which was used in the modeling, corresponding of full replacement of water, that used to dilute the native chicken manure with moisture content of $75 \%$ to moisture content of $90 \%$. Ammonia nitrogen content during liquid phase recirculation under certain conditions was lower than $3000 \mathrm{mg} / \mathrm{dm}^{3}$, which was taken as a safe level for biogas plant operation. The degree of removal of ammonia nitrogen can be significantly increased by changing the geometric dimensions of the biogas reactor, increasing the contact area of the sorbent with the gas phase and increasing the hydraulic retention time. According to the modeling results, the considered method is sufficiently effective for use in the conditions of liquid phase recirculation.
\end{abstract}

DOI: $10.24263 / 2225-2924-2018-24-6-10$ 


\title{
РЕГУЛЮВАННЯ КОНЦЕНТРАЦІЇ АМОНІЙНОГО АЗОТУ ПРИ МЕТАНОВІЙ ФЕРМЕНТАЦІЇ КУРЯЧОГО ПОСЛІДУ В УМОВАХ РЕЦИРКУЛЯЦІЇ РІДКОЇ ФАЗИ
}

\author{
Є.Б. Шаповалов, С.О. Жадан, А.І. Салюк, А.В. Котинський \\ Національний університет харчових технологій
}

У статті наведено оиінку ефективності нового методу регулювання концентрачії інгібітора під час метанової ферментації курячого посліду в умовах рециркуляиії рідкої фази. Суть методу полягає у сорбиії аміаку з газової фази нелетким сорбентом, який знаходиться безпосередньо в реакторі, але не контактує із субстратом. Проведено моделювання концентрації амонійного азоту під час виробництва біогазу з курячого посліду у напівбезперервному режимі без вилучення аміаку та з вилученням. При иьвому використано результати, отримані при дослідженні видалення амонійного азоту з розчинів солі амонію, щзо моделюють субстрат з високою конщентрацією інгібітора, у періодичному режимі. Як сорбент була застосована фосфорна кислота, оскільки вона здатна реагувати з аміаком, є нелеткою, у результаті реакиії утворюється корисний для сільського господарства продукт. Прийнято, що прочес проводиться у термофільному режсим при температурі $50^{\circ} \mathrm{C}$, вологості субстрату $90 \%$ і гідравлічному часі утримання 5 та 10 діб. Концентраиія фосфорної кислоти становить 4 моль/дм. ${ }^{3}$. Значення pH середовища прийнято рівним 7,5, 8,0 i 8,5. Співвідношення площі сорбенту і субстрату становить 1:4,6, а діаметра апарата до глибини субстрату - 1:1,5. Максимальний ступінь рещиркулящії стоку 60\%, який було використано при моделюванні, відповідає повному заміщенню води, що використовується для розбавлення курячого посліду нативної вологості $75 \%$ до вологості 90\%. Вміст амонійного азоту при рециркулящії рідкої фази за

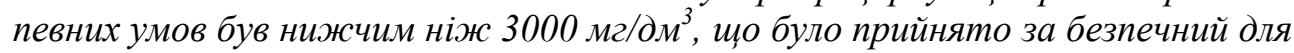
роботи біогазової установки рівень. Ступінь вилучення амонійного азоту може бути суттєво збільшено за рахунок зміни геометричних розмірів біогазової установки, збільшення площі контакту сорбенту з газовою фазою та гідравлічного часу утримання. Відповідно до результатів моделювання, розглянутий метод є достатньо ефективним для його використання в умовах рециркуляиії рідкої фази.

Ключові слова: метанова ферментація, курячий послід, амонійний азот, моделювання, рещиркулячія, рідка фаза.

Постановка проблеми. Рециркуляція рідкої фази під час метанової ферментації курячого посліду дає можливість уникнути проблеми утилізації великої кількості стоків, однак іiі використання лімітується накопиченням інгібіторів у біогазовому реакторі, головним чином, амонійного азоту $[7 ; 8 ; 10]$.

У статті напропоновано новий підхід до видалення амонійного азоту 3 рідкої фази шляхом сорбції аміаку з газової фази нелетким сорбентом, який 
знаходиться безпосередньо в реакторі, але не контактує з субстратом [5]. Можливість його використання було показано як на розчинах, що моделюють субстрат з високою концентрацією інгібітора, так і при безпосередньо метановій ферментації курячого посліду в напівбезперервному режимі [2]. Як сорбент обрано фосфорну кислоту, оскільки вона здатна реагувати з аміаком, $\epsilon$ нелеткою, у результаті реакції утворюється корисний для сільського господарства продукт [4]. Отриманий ефлюент мав понижену концентрацією амонійного азоту, що створює умови для рециркуляції рідкої фази.

Мета дослідження: оцінити ефективність запропонованого методу регулювання концентрації амонійного азоту в біогазовому реакторі в умовах рециркуляції рідкої фази.

Матеріали і методи. Для досягнення поставленої мети, результати, отримані при дослідженні вилучення амонійного азоту з розчинів солі амонію у періодичному режимі [2], були використані для моделювання його вмісту у біогазовому реакторі в умовах рециркуляції рідкої фази.

Зниження концентрації амонійного азоту в розчині об'ємом 0,25 дм³ при початковій концентрації $8000 \mathrm{мг} /$ дм $^{3}$ в результаті сорбції аміаку з газової фази ортофосфорної кислотою 3 концентрацією 4 моль/дм ${ }^{3}$ при температурі $50^{\circ} \mathrm{C}$ апроксимовано функцією:

$$
y=a \cdot e^{-b \cdot x}
$$

де $a$ i $b$ параметри, значення яких залежно від $\mathrm{pH}$ розчину наведено у таблиці.

Таблиия. Значення параметрів функції, що апроксимус зниження концентрації амонійного азоту в розчині

\begin{tabular}{|c|c|c|c|c|}
\hline $\mathrm{pH}$ & $a$ & $b$ & $R^{2}$ & $\sigma$ \\
\hline 7,5 & 8036,6789202 & 0,0030988 & 0,9531770 & 239,8978764 \\
\hline 8,0 & 8064,7175745 & 0,0078838 & 0,9740226 & 259,9980683 \\
\hline 8,5 & 8189,8241458 & 0,0186242 & 0,9785655 & 208,0494536 \\
\hline
\end{tabular}

Для спрощення моделювання концентрації амонійного азоту при метановій ферментації в умовах рециркуляції рідкої фази прийнято, що процес здійснюється у напівбезперевному режимі.

Концентрацію амонійного азоту в реакторі на певний момент часу після початку рециркуляції ефлюенту визначали за формулою:

$$
C_{n+2}=\frac{m_{n+1}}{V}-\frac{m_{n+1}}{V \cdot H R T}+N+\frac{m_{n} \cdot R}{100 \cdot V \cdot H R T}
$$

або у спрощеному вигляді:

$$
C_{n+2}=C_{n+1}-\frac{C_{n+1}}{H R T}+N+\frac{C_{n} \cdot R}{100 \cdot H R T},
$$

де $C$ - концентрація амонійного азоту в біогазовому реакторі, мг/дм ${ }^{3} ; m-$ маса амонійного азоту в біогазовому реакторі, мг; $n-$ номер доби від початку рециркуляції; $V$ - корисний об'єм біогазового реактора, дм ${ }^{3} ; H R T-$ гідравлічний час утримання, діб; $R-$ ступінь рециркуляції, \%; $N-$ маса амонійного азоту, що поступає в біогазовий реактор з курячим послідом, мг. 
Концентрацію амонійного азоту в реакторі, у якому проходить сорбція аміаку 3 газової фази, на певний момент часу після початку рециркуляції ефлюенту визначали за формулою:

$$
C_{n+2}=C_{n+1}-\frac{C_{n+1}}{H R T}+N+\frac{C_{n} \cdot R}{100 \cdot H R T}-s\left(C_{n}, C_{n+1}, H R T, N, R, a, b\right),
$$

де $s$ - маса амонійного азоту, що видаляється з рідкої фази за рахунок сорбції аміаку з газової фази протягом доби, мг; $a$ та $b-$ значення параметрів функції, що апроксимує зниження концентрації амонійного азоту в розчині у періодичному режимі.

Значення $s$ визначається за формулою:

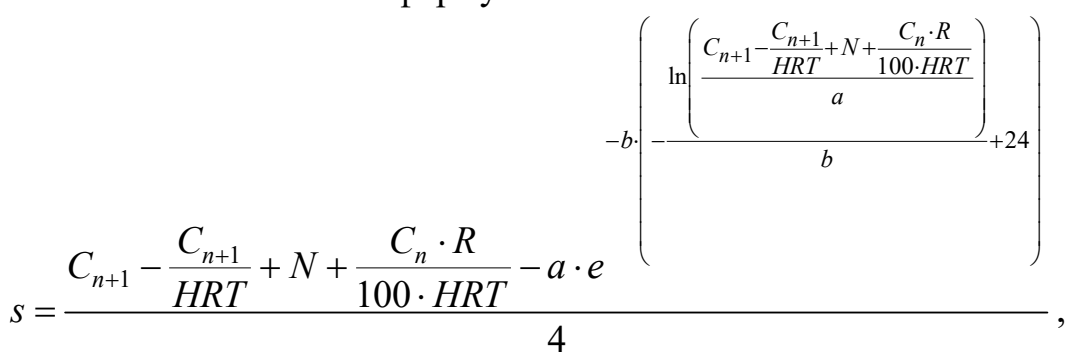

де 4 - коефіцієнт, що враховує приведення вилучення амонійного азоту до одиниці об'єму.

Наведені вище формули враховують порядок дій при обслуговуванні біогазової установки:

- ефлюент у кількості $V / H R T$ зливається з апарата;

- курячий послід розбавляється водою та ефлюентом у кількості $V R /(100 H R T)$;

- отриманий субстрат подається в біогазовий реактор.

Прийнято, що процес проводиться у термофільному режимі при температурі $50^{\circ} \mathrm{C}$, вологості субстрату $90 \%$ і гідравлічному часі утримання 5 та 10 діб. Концентрація фосфорної кислоти становить 4 моль/дм³. Значення $\mathrm{pH}$ середовища прийнято рівним 7,5, 8,0 і 8,5. Співвідношення площі сорбенту i субстрату становить $1: 4,6$, а діаметра апарата до глибини субстрату - 1:1,5. Концентрацію амонійного азоту в біогазовому реакторі без вилучення амонійного азоту прийнято рівною 3000 мг/дм ${ }^{3}$ [2].

Математичне моделювання виконано 3 використанням системи комп'ютерної алгебри Mathcad 15.

Результати і обговорення. Результати моделювання вмісту амонійного азоту в біогазовому реакторі на певний момент часу після початку рециркуляції ефлюенту наведено на рис. 1 .

Максимальний ступінь рециркуляції стоку 60\%, відображений на графіках, відповідає повному заміщенню води, що використовується для розбавлення курячого посліду нативної вологості $75 \%$ до вологості $90 \%$.

У результаті аналізу отриманих графіків відзначено такі закономірності: більший ступінь рециркуляції обумовлює більшу концентрацію амонійного азоту в реакторі; швидкість збільшення концентрації амонійного азоту від початку рециркуляції непостійна і з часом зменшується; чим більший час гідравлічного утримання та вищий ступінь рециркуляції, тим більше часу потрібно для досягнення максимальної концентрації амонійного азоту. 


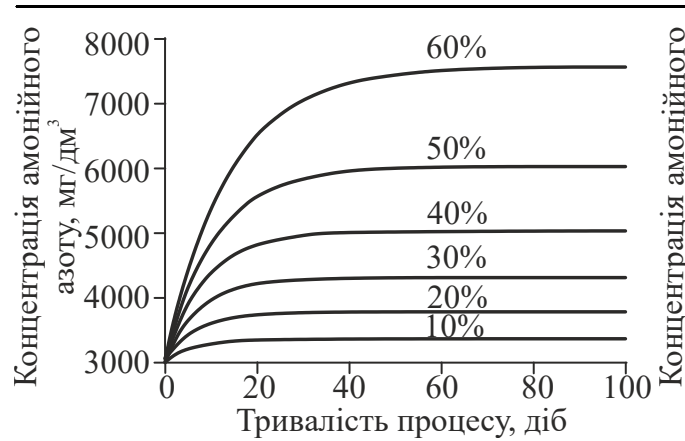

a)

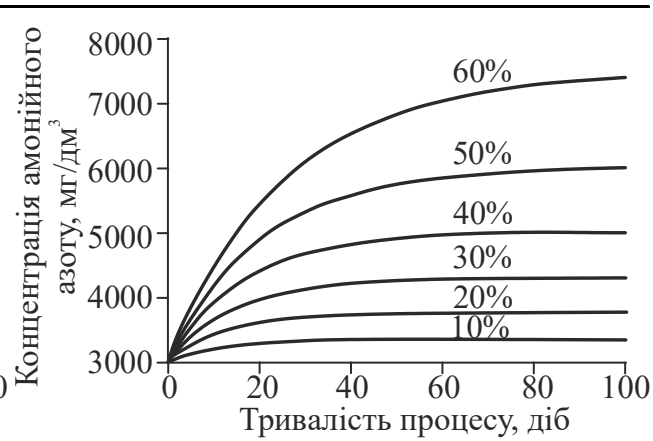

б)

Рис. 1. Концентрація амонійного азоту в реакторі 3 HRT 5 діб

a) та HRT 10 діб б) після початку рециркуляції ефлюенту за різного ступеня

Результати моделювання вмісту амонійного азоту в біогазовому реакторі, у якому проходить сорбція аміаку з газової фази, на певний момент часу після початку рециркуляції ефлюенту наведено на рис. 2, 3 та 4.

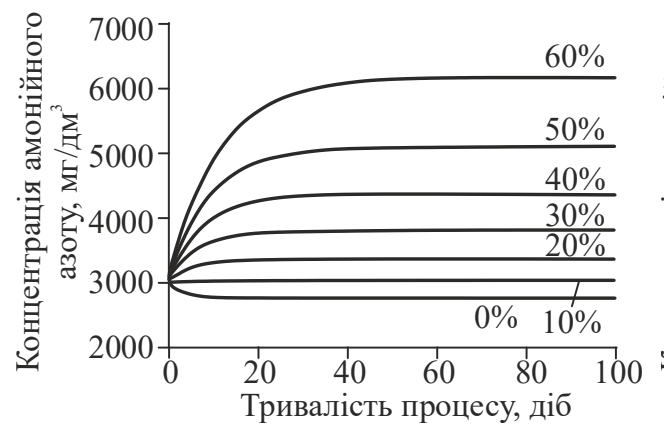

a)

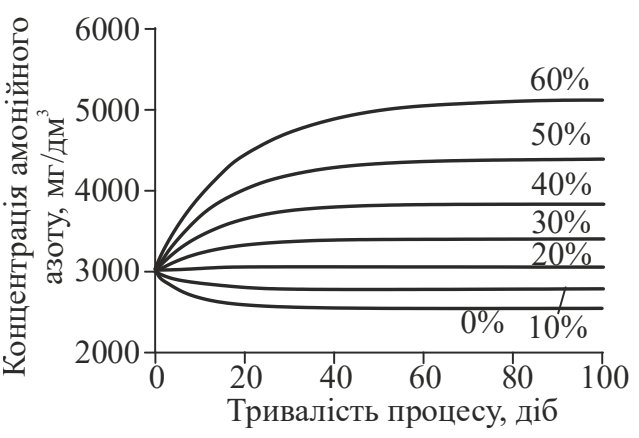

б)

Рис. 2. Концентрація амонійного азоту в реакторі з НRT 5 діб

a) та HRT 10 діб б), у якому проходить сорбція аміаку з газової фази при рН рідкої фази 7,5, після початку рециркуляції ефлюенту за різного ступеня

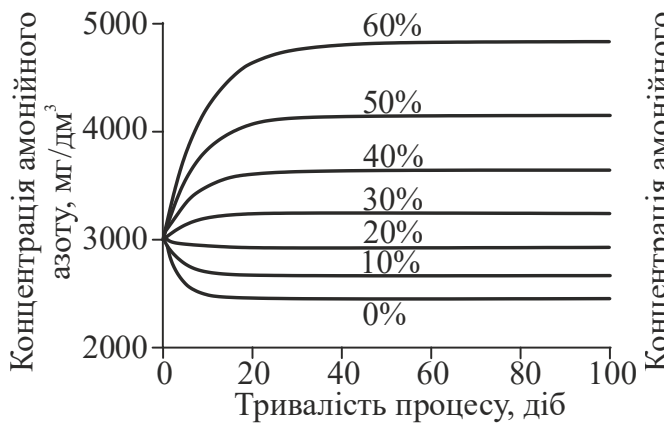

a)

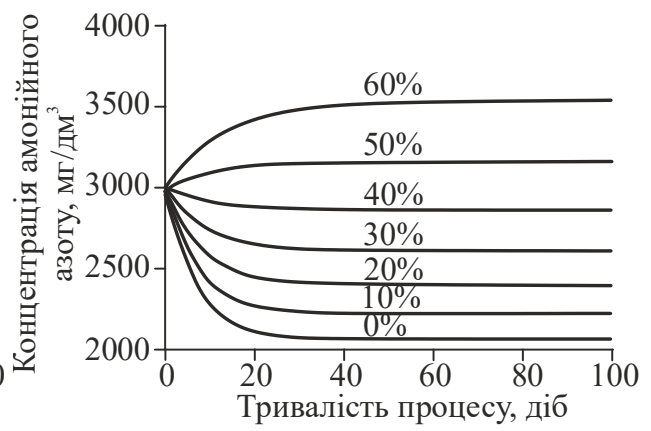

б)

Рис. 3. Концентрація амонійного азоту в реакторі з HRT 5 діб

a) та HRT 10 діб б), у якому проходить сорбція аміаку з газової фази при рН рідкої фази 8,0, після початку рециркуляції ефлюенту за різного ступеня 


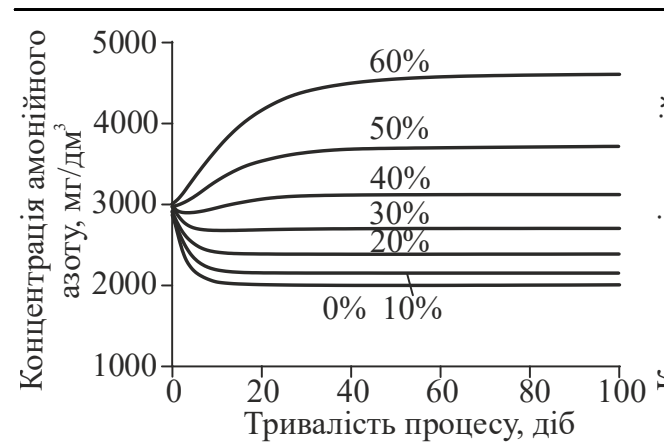

a)

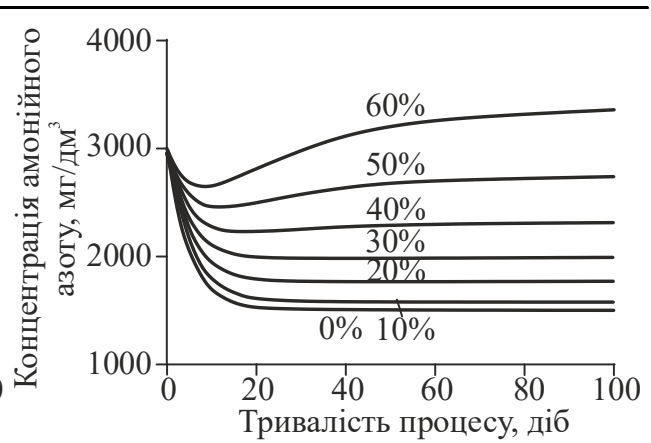

б)

Рис. 4. Концентрація амонійного азоту в реакторі з HRT 5 діб

a) та HRT 10 діб б), у якому проходить сорбція аміаку з газової фази при рН рідкої фази 8,5 , після початку рециркуляції ефлюенту за різного ступеня

При гідравлічному часі утримання 10 діб концентрація амонійного азоту була меншою, ніж при гідравлічному часі утримання 5 діб. Це обумовлено тим, що субстрат знаходиться у реакторі довше, відповідно, і сорбція аміаку триває більше часу.

При підвищенні рН рідкої фази з 7,5 до 8,5 концентрація амонійного азоту у реакторі зменшувалась. Це обумовлено тим, що при вищому значенні $\mathrm{pH}$ швидкість вилучення амонійного азоту є вищою.

Початкове зниження концентрації амонійного азоту в апараті з подальшим його збільшенням на деяких графіках пояснюється моделюванням процесу у напівбезперервному режимі.

За результатами моделювання, використання сорбції аміаку з газової фази матиме значний вплив на концентрацію амонійного азоту в біогазовому реакторі під час метанової ферментації курячого посліду.

Маккарті показав, що при концентрації амонійного азоту, яка перевищує 3000 мг $\mathrm{N}^{-\mathrm{NH}_{4}}{ }^{+} /$дм$^{3}$, процес анаеробної ферментації є інгібованим при будьякому значенні $\mathrm{pH}[9]$.

Запропонований метод регулювання вмісту амонійного азоту, в ряді випадків, дає змогу тримати його концентрацію нижчою від наведеного значення навіть в умовах рециркуляції рідкої фази.

Ступінь вилучення амонійного азоту може бути суттєво збільшено за рахунок зміни геометричних розмірів біогазової установки, збільшення площі контакту сорбенту з газовою фазою та гідравлічного часу утримання.

Так, зменшення висоти субстрату в біогазовому реакторі вдвічі при збереженні площі контакту рідкої фази з газовою призведе до збільшення швидкості вилучення амонійного азоту у відповідну кількість разів.

У дослідженні з вилучення амонійного азоту з розчинів солей амонію, що моделюють субстрат з високою концентрацією інгібітора, підвищення концентрації розчину фосфорної кислоти 34 моль/дм³ до 6 моль/дм призводило до збільшення швидкості вилучення амонійного азоту з рідкої фази [2], що свідчить про відсутність лімітування процесу переходом аміаку з рідкої фази в газову. Виходячи 3 цього, при концентрації кислоти 4 моль/дм³ швидкість 
вилучення амонійного азоту можна підвищити шляхом збільшення площі поверхні сорбенту.

Слід відзначити, що використання розчину кислоти з більшою концентрацією є недоцільним через гігроскопічність кислоти [2; 4].

Гідравлічний час утримання в термофільному режимі приймається рівним 5-10 діб [1]. Такий діапазон використовувався під час моделювання концентрації амонійного азоту в біогазовому реакторі. Використання збільшеного часу гідравлічного утримання буде відповідати європейській практиці. Так, згідно $з$ даними Едер і Шульца, гідравлічний час утримання в термофільному режимі приймається рівним 15-25 діб [6].

Конкретне значення часу гідравлічного утримання при метановій ферментації курячого посліду, що відповідає певному критерію оптимізації виробництва біогазу, наведено в [3].

Проведене моделювання має такі недоліки: рівень рН приймається постійним; ступінь амоніфікації приймається однаковим незалежно від гідравлічного часу утримання.

У реальних умовах зменшення вмісту амонійного азоту супроводжується зниженням значення рН. Однак таке зниження під час метанової ферментації курячого посліду за рахунок буферної ємності системи не є значним.

Гідравлічний час утримання впливає на ступінь деструкції органічних речовин, у тому числі тих, що є джерелом утворення амонійного азоту. Однак при метановій ферментації курячого посліду основна його частина виділяється достатньо швидко. Джерелами утворення амонійного азоту є сечова кислота і неперетравлені білки. Вони представляють 70\% і 30\% загального азоту, відповідно [11]. Лейсі і співавтори повідомили про повну утилізацію сечової кислоти після перших 24 год при анаеробній переробці курячого посліду, розбавленого до вологості 95\% [12].

\section{Висновки}

Відповідно до результатів моделювання новий метод регулювання концентрації амонійного азоту, який полягає у сорбції аміаку з газової фази нелетким сорбентом, що знаходиться безпосередньо в реакторі, але не контактує 3 субстратом, є достатньо ефективним для його використання під час метанової ферментації курячого посліду в умовах рециркуляції рідкої фази.

\section{Лiтература}

1. Биогазовые технологии в Кыргызской Республике: справочное руководство / [А.Г. Веденев, Т.А. Веденева, ОФ «Флюид»]. Бишкек: Евро, 2006. 90 с.

2. Салюк А.И., Жадан С.А., Шаповалов Е.Б., Тарасенко Р.А. Метановая ферментация куриного помета при пониженной концентрации ингибиторов. International Scientific Journal for Alternative Energy and Ecology (ISJAEE). 2017. № 4. C. 89—98.

3. Салюк А.І., Котинський А.В., Жадан С.О., Шаповалов С.Б. Режими метанової ферментації курячого посліду. Наукові праці Національного університету харчових технологій. 2017. Т. 23(2). С. 31-36.

4. Спосіб одержання твердого мінерального добрива при метановій ферментації: пат. 114655 Україна: МПК (2017.01) C05F 3/00. № 201610452; заявл. 17.10.2016; опубл. 10.03.2017; Бюл. №5. 3 с. 
5. Спосіб отримання біогазу та добрива з відходів з високим вмістом азоту: пат. 105080 Україна: МПК (2016.01) C05F 3/00. № 201505811; заявл. 12.06.2015; опубл. 10.03.2016. Бюл. № 5.1 с.

6. Эдер Б., Шульц Х. Биогазовые установки: практическое пособие. Zorg Biogas, 1996. URL: http://zorgbiogas.ru/upload/pdf/Biogas_plants_Practics.pdf(дата обращения: 09.11.2017).

7. Belostotskiy D., Jacobi H., Strach K., Liebetrau J. Anaerobic digestion of chicken manure as a single substrate by control of ammonia concentration. URL: http://www.redbiogas.cl/wpcontent/uploads/2013/07/IWA-11342.pdf(Last accessed: 09.11.2017).

8. Integrated Approach to Sustain Biogas Production in Anaerobic Digestion of Chicken Manure under Recycled Utilization of Liquid Digestate: Dynamics of Ammonium Accumulation and Mitigation Control / S. Wu, P. Ni, J. Li, et. al. Bioresource Technology. 2016. № 205. P. $75-81$.

9. McCarty P.L. Anaerobic waste treatment fundamentals III. Public Works. 1964. № 95. P. 91.

10. Mono-fermentation of chicken manure: Ammonia inhibition and recirculation of the digestate / H. Nie, H. Jacobi, K. Strach, et. al. Bioresource Technology. 2015. № 178. P. 238-246.

11. Nakashimada Y., Abouelenien F., Nishio N. Novel uric acid degrading bacteria isolated from dry methanogenic sludge of chicken manure. HU-AIST Biomass seminar, January 13, 2013. URL: https://unit.aist.go.jp/chugoku/even/BiomassOpenSeminar/No16/report1.pdf (Last accessed: 20.08.2015).

12. Nutrient changes in poultry manure during batch liquid phase anaerobic fermentation / R.E. Lacey, I.J. Ross, J.L. Taraba, L.R. Walton. Livestock Waste: A Renewable Resource (Fourth International Symposium on Livestock Wastes, Amarillo Civic Center, Amarillo, Texas, 1980). Amarillo: ASAE Publication. 1981. P. 31-33. 